\title{
Verlags-Anzeigen.
}

Neuer Verlag von Theobald Grieben in Berlin.

\section{Ornithologische Briefe.}

Blätter der Erinnerung an seine Freunde, gesammelt von

E. F. von Homeyer. -6 Mark.

Wissenschaftliche Mittheilungen von Bädeker, C. L. Brehm, Gaetke, von Homeyer, Kjärbölling, Landbeck, v. Loebenstein, Max Prinz von Wied, Naumann, Radde, Ratzeburg, Thienemann, Tobias, Zander, Zittwitz etc.

Just. completed, subscription price L. 12,12 sh.

\section{Captain G. E. Shelley's}

\section{Monograph of} the Nectariniidae

\section{Family of Sun-Birds}

\author{
complete in 12 parts. impl. 4to
}

$500 \mathrm{Pp}$. of text, with 120 finely coloured plates.

For a short time only am I able to supply this beautiful and most accurate work at this price. The 250 copies printed are nearly all subscribed for.

Bernard Quaritch, 15 Piccadilly, London.

\section{Indian Ornithology.}

Just Completed.

Hume (Allan) and Marshall (C. H. S.).

the Game Birds of India. Burmah and Ceylon. royal 8 vo. 3 vols. containing 140 fine coloured plates of Birds and 4 of Eggs. cloth. L. 6 .

\section{Contents:}

(Calcutta $1878-80$ ).

Vol. I. the Bustards, Florican, Sandgrouse, Peafowl, Pheasants, Jungle Fowl and Spur-Fowl.

Vol. II. the Partridges, Quails, Crakes and Rails.

Vol. III. the Cranes, Swans, Geese, Duck, Teal, Snipe, Godwits Woodcock etc.

Very few copies remain for sale in England.

Bernard Quaritch, 15 Piccadilly, London. 


\section{$2 \mathrm{BHL}$ Biodiversity Heritage Library}

1881. "Verlags-Anzeigen." Journal

$f u$

r Ornithologie 29, 224-224. https://doi.org/10.1007/bf02007663.

View This Item Online: https://www.biodiversitylibrary.org/item/102782

DOI: https://doi.org/10.1007/bf02007663

Permalink: https://www.biodiversitylibrary.org/partpdf/142845

\section{Holding Institution}

Smithsonian Libraries

\section{Sponsored by}

Biodiversity Heritage Library

\section{Copyright \& Reuse}

Copyright Status: Public domain. The BHL considers that this work is no longer under copyright protection.

This document was created from content at the Biodiversity Heritage Library, the world's largest open access digital library for biodiversity literature and archives. Visit BHL at https://www.biodiversitylibrary.org. 